\title{
Micro-structural analysis of recycled aggregate concrete produced from two-stage mixing approach
}

\author{
Vivian W. Y. Tam ${ }^{1}$, X. F. Gao ${ }^{2}$ and C. M. Tam ${ }^{3} *$ \\ ${ }^{1}$ Department of Building \& Construction, City University of Hong Kong, 83 Tat Chee Avenue, Kowloon, Hong \\ Kong. \\ Email: tam.vivian@student.cityu.edu.hk, Tel: (852) 2784-4377, Fax: (852) 2788-7612. \\ ${ }^{2}$ Faculty of Science, Xi'an Jiaotong University, Xi'an, 710049, PRChina. \\ 3* Correspondence author, Department of Building \& Construction, City University of Hong Kong, 83 Tat Chee \\ Avenue, Kowloon, Hong Kong. \\ Email: bctam@cityu.edu.hk, Tel: (852) 2788-7620, Fax: (852) 2788-7612.
}

\begin{abstract}
Owing to the shortage of space for land reclamation in Hong Kong, it is difficult to dispose of tons of masonry waste generated daily from construction activities. Adoption of recycled aggregate from concrete waste thus becomes a burning issue. The Hong Kong SAR Government has set up a recycling plant in Tuen Mun Area 38 aiming at turning concrete waste into recycled aggregate with a practice note and specifications issued for controlling the quality of recycled aggregate. However, the use of recycled aggregate concrete to high grade applications is rarely reported because of its poorer compressive strength and high variability in mechanical behavior. This paper proposes a new approach in mixing concrete, namely "two-stage mixing approach (TSMA)", intended to improve the compressive strength for recycled aggregate concrete and hence lower its strength variability. Based upon experimental works, improvements in strength to recycled aggregate concrete were achieved. The effect can be attributable to the porous nature of the recycled aggregate and hence the pre-mix process can fill up some pores and cracks, resulting in a denser concrete, an improved interfacial zone around recycled aggregate and thus a higher strength when compared with the traditional mixing approach.
\end{abstract}

Keywords: Compressive Strength, Two-stage Mixing Approach, Recycled Aggregate 
Concrete, Waste Management, Construction

\section{Introduction}

As sustainability is a pressing issue all over the world, the word "recycle" forms one of the most important keywords today [1]. Recycling and resource saving have been advocated in the construction industry, but the effectiveness of these has been constrained because the conditions in applying these approaches were not provided [2]. These conditions include the lack of site space and equipment for waste sorting, experience in waste recycling operations, trained supervisors and employees, knowledge of secondary materials markets, environmental and safety regulations.

In Denmark, Netherlands and Japan, there have been records of eighty, seventy-five and sixtyfive percent of recycling rates [3-5]. To achieve these rates, special site arrangements such as selective demolition need to be implemented. Different types of materials (bricks and masonry, roofing tiles, concrete and timber) need to be removed separately as much as possible [5] and sorted at the source to facilitate recycling. Recovery of materials from these wastes can reduce the consumption of landfill areas and natural gravel resources. Although the recycling rate is high in some countries, the use of recycled aggregate (RA) is confined to low grade applications such as unbound road base, fill and hardcore. For higher grade applications, new recycling technology needs to be developed. In Japan, higher-grade utilization of concrete has been recorded, leading to a recycling rate of $65 \%$ for concrete [5]. One of these is the use of RA as aggregate for new structural concrete. Similarly, in the United Kingdom, it is the government policy to increase the level of RA to promote natural resources conservation and improve environmental protection [6]. 
The use of recycled aggregate has been strongly advocated in Hong Kong [6-10]. Various government departments have been encouraging adoption of recycled aggregate. The Civil Engineering Department of the Hong Kong Special Administrative Region (HKSAR) has set up a recycling plant to produce recycled aggregate in Tuen Mun Area 38; the Buildings Department of HKSAR has issued a practice note on "Use of recycled aggregates in concrete"; and the Environment, Transport and Works Bureau has published a Technical Circular (Ref: 12/2002) entitled "Specifications facilitating the use of recycled aggregates". All aims at promoting the use of recycled aggregate and setting standards and practice guidelines for the product. The Architectural Services Department of HKSAR has examined the possibility of using 20\% recycled aggregate for project development and the Hong Kong Housing Authority of HKSAR and local universities are finding ways to improve the quality of recycled aggregate. Under the above context, this paper aims to achieve the following objectives:

i) Examining the current practices in the applications of recycled aggregate concrete (RAC);

ii) Proposing the two-stage mixing approach (TSMA) to improve the quality of RAC;

iii) Experimenting the TSMA and assessing the benefits possibly gained; and

iv) Conducting micro-structural analyses to explore the mechanism of TSMA.

\section{Recycled Aggregate Concrete}

As revealed from previous studies, the quality of aggregate is commonly classified according to the absorption rates [11]. High absorption indicates high level of cement mortar attachment, which generally leads to concrete with inferior strength, durability and deformation and shrinkage properties. Accordingly, the maximum allowable design strength and the members and portions to which such concrete may be applied are limited. From the research of [11], three types of RA are classified: Type C1, C2 and C3 for recycled coarse aggregate and Type 
F1 and F2 for recycled fine aggregate (see Table 1). For the recycled coarse aggregate, Type C1 has the best quality with the lowest water absorption rate of $3 \%$ or less and sulfate soundness of $12 \%$ or less, while recycled coarse aggregate Type C3 is designed to have $7 \%$ or less of water absorption. For the recycled fine aggregate, Type F1 and F2 are designed to have $5 \%$ or less and $10 \%$ or less of water absorption respectively.

From these three types of recycled coarse aggregate: C1, C2 and C3 and two types of recycled fine aggregate: F1 and F2, four types of suggested RAC applications are recommended for civil and building works as tabulated in Table 2. Among the three types of civil engineering applications of RAC, namely CI, CII and CIII with respect to different combinations of recycled coarse aggregate and recycled fine aggregate (see Table 1), Type CI RAC can be designed up to 18 to $24 \mathrm{MPa}$, thus suitable for reinforced and plain concrete, lower structure of bridges, tunnel lining and retaining walls. The four types of building work applications of RAC, namely BI, BII, BIII and BIV (see Table 1) can all be designed with a strength of 18 MPa or higher, for various types of application including ordinary reinforced concrete building structures, foundations, foundation slabs and backfilling concrete respectively. Several potential areas in the application of recycled material are tabulated in Table 3.

\section{Materials and Methods}

Since there are many unsolved problems encountered in controlling the quality of RAC, which include low compressive strength, wide variability of quality, high drying shrinkage, large creep and low elastic modulus [11-12], applications of RAC are hampered. These problems are mainly resulted from the following two reasons:

- $\quad$ Concrete wastes are always contaminated with foreign materials; and

- $\quad$ Recycled aggregate particles are always attached with substantial amount of 
Under normal situations, some modifications to the mix proportion are needed in the production of RAC, which can then be produced with the same production procedure as the conventional concrete does. However, such an approach will produce concrete with poorer quality, depending directly on the proportion of RA added. Hence, most studies recommend a limit of 30 percent of RA [14]. Many researchers have successfully applied RA on pavement and roadwork [15-17] or simple structures, underground structures, foundations, piles, and mass concrete [18]. However, its application to higher-grade concrete is not common.

These weaknesses of RA, including high porosity, high amount of cracks, high level of sulphate and chloride contents, high level of impurity and high cement mortar remains, will affect the mechanical performance of RAC [19]. The pre-requisite in applying RA to high grade concrete is to overcome these weaknesses. A new mixing approach: Two-Stage Mixing Approach (TSMA) is proposed. For NMA, the mixer is firstly charged with about one half of coarse aggregate, then with fine aggregate, then with cement and finally with the remaining coarse aggregate. Water is then added immediately before the rotation of the drum or starting the pan [20], while TSMA divides the mixing process into two parts and proportionally splits the required water into two which are added at different timing. Figure 1 illustrates the TSMA mixing procedure while Table 4 shows the symbols used.

The RA adopted in experimenting NMA and TSMA collected from Tuen Mun Area 38 recycling plant has water absorption values of $1.65 \%$ for $20 \mathrm{~mm}$ and $2.63 \%$ for $10 \mathrm{~mm}$ aggregate; while the moisture contents are $0.33 \%$ and $0.49 \%$ for $20 \mathrm{~mm}$ and $10 \mathrm{~mm}$ 
respectively according to BS 812: Part 109 [21]. The quality of RA is weaker than that of virgin aggregate (water absorption of virgin aggregate at only $0.77 \%$ and $0.57 \%$ for $20 \mathrm{~mm}$ and $10 \mathrm{~mm}$ respectively), indicating that the major weakness of RA is its high porosity.

As most studies recommend a limit of $30 \%$ percentage of RA used, $0 \%, 10 \%, 15 \%, 20 \%$, $25 \%$ and $30 \%$ of RA have been experimented using the NMA and TSMA with the designated mix proportions according to the specifications of Buildings Department (BD) [22] with a water to cement ratio of 0.45 (see Table 5). The compressive strengths of the mixes are then compared, which is one of the most important mechanical properties of concrete in concrete mix design. 100mm sized cubes are used for testing compressive strength development under the standard curing conditions for 7, 14, 28 and 56 days. Three cubes of 7, 14, 28 and 56 days were tested and the average was taken according to BS 1881: Part 116 [23].

\section{Results and Discussion}

All the mix proportions of recycled aggregate concrete using TSMA and NMA are controlled with slump of $75 \mathrm{~mm}$ as required by $\mathrm{BD}$ [22]. The results of compressive strengths and the percentages of improvement in different proportions of RA using NMA and TSMA are tabulated in Table 6 with the improvement trends for 7-day, 14-day, 28-day and 56-day strengths shown in Figures 2 to 5 respectively. As shown in Figures 2 to 5, a clear strength enhancement in using TSMA can be found when compared with that of NMA. In general, gradual improvements in strength with increased percentages of RA can be observed when using TSMA.

Concrete is of a three-phase system, comprising coarse aggregate, mortar matrix with fine aggregate, and interfacial zones (ITZ) between coarse aggregate and the mortar matrix [24- 
26]. In concrete, the interfacial zone between cement paste and aggregate plays a critical role. At the macroscopic level, concrete is a composite material consisting of discrete aggregates dispersed in a continuous cement-paste matrix [27]. As with other composites, the bond between these two major components of concrete critically determines the mechanical performance.

Though the ITZ itself is quite narrow, it occupies a relatively large proportion of the cement paste. In a typical concrete composite, the mean spacing between aggregate particles is 75 to $100 \mu \mathrm{m}$. Assuming a $40 \mu \mathrm{m}$ thickness for the ITZ, it has been estimated that the ITZ makes up 20 to 40 percent of the total volume of the cementitious matrix [28]. The weakness of the interfacial zone inhibits the achievement of composite action in normal strength concrete [29]. Hence, the interfacial region is generally regarded as the 'weak link' in concrete [30-35].

In fact, the structure of RAC is much more complicated than that in normal concrete. RAC possesses two ITZs, one between the RA and new cement paste (new ITZ), and the other between the RA and the old mortar attached (old ITZ), which are schematically shown in Figure 6. The cement mortar remains at the ITZ of RA form the weak link in RAC, which is composed of many minute pores and cracks and they critically affect the ultimate strength of the RAC. These pores and cracks increase consumption of water leading to less water for hydration at the ITZ of RAC.

During the first stage of mixing, TSMA uses half of the required water for mixing leading to the formation of a thin layer of cement slurry on the surface of RA which will permeate into the porous old cement mortar, filling up the old cracks and voids. At the second stage of mixing, the remaining water is added to complete the concrete mixing process. Under the 
examination of scanning electron microscopy (SEM), the cracks within RA are filled after adopting TSMA (see Figure 7), while similar cracks in RA still remain unfilled for NMA (see Figure 8). Further, more voids and cracks are found between RA and mortar for NMA (see Figures 9 and 10) since complete hydration of the mortar at ITZ is hampered due to inadequacy of water. Figures 11 and 12 show the SEM photography of the dense and loose cement paste mixed by TSMA and NMA respectively.

The experiments show that the two-stage mixing approach can enhance the compressive strength of RAC by developing a stronger interfacial zone. The quality of ITZ depends on surface characteristics of the aggregate particles, the degree of bleeding, chemical bonding and the specimen preparation technique which, however, are notoriously difficult to measure. Although these effects have been reported by some investigations, the results are difficult to reconcile. Nonetheless, it is generally agreed that as the paste-aggregate bond strength increases, the concrete strength also increases [28].

Under the examination of SEM, both the new interfacial zone and old interfacial zone of RAC are identified. Figure 13 shows a stronger and denser new interfacial zone in RAC after adopting TSMA, compared to the poorer ITZ for NMA shown in Figure 14. Figure 15 shows a stronger and denser old interfacial zone around RA after adopting TSMA, compared to the old ITZ for NMA as shown in Figures 16 and 17. It is clearly seen that both the new and old interfacial zones for TSMA are stronger than those for NMA. Therefore, the two-stage mixing approach can improve the ITZ of RA and thus the compressive strength of the RAC. Figure 18 illustrates the concrete matrix scenario for TSMA schematically.

\section{Conclusion}


The poor quality of RAC resulted from the higher water absorption, higher porosity, weaker ITZ between RA and new cement mortar hampers the application of RAC for higher grade applications. In this study, the two-stage mixing approach is proposed to strength the weak link of RAC, which is located at the interfacial transition zone (ITZ) of the RA. The two-stage mixing approach gives way for the cement slurry to gel up the RA, providing a stronger ITZ by filling up the cracks and pores within RA. From the laboratory experiments, the compressive strengths have been improved. This two-stage mixing approach can provide an effective method for enhancing the compressive strength and other mechanical performance of RAC and thus the approach opens up a wider scope of RAC applications.

\section{Acknowledgments}

The work described in this paper was fully supported by a grant from the Housing Authority Research Fund of the Hong Kong Special Administrative Region, China (Project Ref. No. 9460004).

\section{References}

1. H. Kawano, The state of reuse of demolished concrete in Japan, Integrated design and environmental issues in concrete technology: proceedings of the International Workshop 'Rational Design of Concrete Structures under Severe Conditions': Hakodate, Japan, 7-9 August 1995. E \& FN Spon. London, (1995) 243-249.

2. L. P. Chun, D. E. Scorpio, C. J. Kibert, Strategies for successful construction and demolition waste recycling operations, Journal of Construction Management and Economics 15 (1) (1997) 49-58.

3. CMRA (Construction Materials Recycling Association), Homepage, available at http://www.cdrecycling.org/ (2003). 
4. EPD (Environmental Protection Department), Homepage, available at http://www.info.gov.hk/epd (2003).

5. C. F. Hendriks, H. S. Pietersen, Sustainable raw materials: construction and demolition waste, Cachan Cedex, RILEM Publication, France (2000).

6. R. J. Collins, Reuse of demolition materials in relation to specifications in the UK, Demolition and reuse of concrete and masonry: guidelines for demolition and reuse of concrete and masonry: proceedings of the Third International RILEM Symposium on Demolition and Reuse of Concrete Masonry, held in Odense, Denmark, 24-27 October 1993, E \& FN Spon, London (1993) 49-56.

7. CIRIA, Environmental issues in construction: a review of issues and initiatives relevant to construction and related industries, V. 2, Technical Review, Special Publication 94, Construction Industry Research and Information Association, London (1993).

8. C. F. Hendriks, Certification system for aggregates produced from building waste and demolished buildings, Environmental aspects of construction with waste materials : proceeding[s] of the International Conference on Environmental Implications of Construction Materials and Technology Developments, Maastricht, the Netherlands, 1-3 June 1994 (1994) 821-834.

9. M. Mulheron, The recycling of demolition debris: current practice, products and standards in the United Kingdom, Demolition and reuse of concrete and masonry: reuse of demolition waste, Chapman and Hall, London (1988) 510-519.

10. M. Torring, Management of concrete demolition waste, Concrete technology for a sustainable development in the 21st century, New York: E \& FN Spon, London (2000) 321-331.

11. F. Tomosawa, T. Noguchi, New technology for the recycling of concrete - Japanese experience, Concrete technology for a sustainable development in the 21st century, New 
York: E \& FN Spon, London (2000) 274-287.

12. T. Nogchi, M. Tamura, Concrete design towards complete recycling, Structural Concrete 2 (3) (2001) 155-167.

13. R. S. Ravindrarajah, C. T. Tam, Methods of improving the quality of recycled aggregate concrete, Demolition and reuse of concrete and masonry: reuse of demolition waste, London: Chapman and Hall (1988) 575-584.

14. M. Kikuchi, T. Mukai, H. Koizumi, Properties of concrete products containing recycled aggregate, Demolition and reuse of concrete and masonry: reuse of demolition waste, Chapman and Hall, London (1988) 595-604.

15. H. K. Cheung, Use of recycled asphalt pavement - a practical approach to asphalt recycling, Materials Science and Technology in Engineering Conference - Now, New and Next 15-17 January 2003 (2003).

16. K. E. Hassan, J. J. Brooks, M. Erdman, The use of reclaimed asphalt pavement aggregates in concrete, Waste materials in construction: WASCON 2000: proceedings of the International Conference on the Science and Engineering of Recycling for Environmental Protection, Harrogate, England, 31 May, 1-2 June 2000 (2000) 121-128.

17. C. S. Poon, S. Azhar, S. C. Kou, Recycled aggregates for concrete applications, Materials Science and Technology in Engineering Conference - Now, New and Next 15-17 January 2003 (2003).

18. K. Yoda, T. Yoshikane, Y. Nakashima, T. Soshiroda, Recycled cement and recycled concrete in Japan, Demolition and reuse of concrete and masonry: reuse of demolition waste, Chapman and Hall, London (1988) 527-536.

19. J. S. Ryu, An experimental study on the effect of recycled aggregate on concrete properties, Magazine of Concrete Research 54 (1) (2002) 7-12.

20. Hong Kong Government, Construction standard: testing concrete, Hong Kong 
21. BS 812: Part 109. Methods for determination of moisture content. British Standards Institution, London, United Kingdom (1990).

22. BD (Buildings Department), Homepage, available at http://www.info.gov.hk/bd/english/index.html (2004).

23. BS 812: Part 116, Methods for determination of compressive strength of concrete cubes, British Standards Institution, London, United Kingdom (1983).

24. A. K. H. Kwan, Z. M. Wang, H. C. Chan, Mesoscopic study of concrete II: nonlinear finite element analysis, Computers and Structures 70 (5) (1999) 545-556.

25. M. A. Tasdemir, C. Tasdemir, S. Akyuz, A. D. Jefferson, F. D. Lydon, B. I. G. Barr, Evaluation of strains at peak stresses in concrete: a three-phase composite model approach, Cement and Concrete Composites 20 (4) (1998) 301-318.

26. Z. M. Wang, A. K. H. Kwan and H. C. Chan, Mesoscopic study of concrete I: generation of random aggregate structure and finite element mesh, Computers and Structures 70 (5) (1999) 533-544.

27. D. P. Bentz, E. J. Garboczi, Simulation studies of the effects of mineral admixtures on the cement paste-aggregate interfacial zone, ACI Materials Journal September-October (1991) 518-529.

28. S. Mindess, J. F. Young, D. Darwin, Concrete, Upper Saddle River, NJ: Prentice Hall (2003).

29. P. K. Mehta, P. C. Aitcin, Microstructural basis of selection of materials and mix proportions for high strength concrete, High Strength Concrete, Second International Symposium, ACI SP-121 (1990) 265-279.

30. M. G. Alexander, The effects of ageing on the interfacial zone in concrete, Interfacial transition zone in concrete: state-of-the-art report (1996) 150-174. 
31. W. Jia, L. Baoyuan, X. Songshan, W. Zhongwei, Improvement of paste-aggregate interface by adding silica fume, Proceedings of the $8^{\text {th }}$ International Congress on the Chemistry of Cement, Vol. III (1986) 460-465.

32. W. Keru, Z. Jianhua, The influence of the matrix-aggregate bond on the strength and brittleness of concrete, Bonding in Cementitious Composites, Materials Research Society Vol. 114 (1988) 29-34.

33. G. Li, H. Xie, G. Xiong, Transition zone studies of new-to-old concrete with different binders, Cement and Concrete Composites 23 (4-5) (2001) 381-387.

34. S. Popovics, Attempts to improve the bond between cement paste and aggregate, Materials and Structures 20 (115) (1987) 32-38.

35. W. Xueqan, L. Dongxu, B. Qinghan, G. Liqun, T. Mingshu, Preliminary study of a composite process in concrete manufacture, Cement and Concrete Research 17 (5) (1987) 709-714. 
Table 1: Quality Standard of Recycled Aggregate Concrete for Public Works [11]

\begin{tabular}{|c|c|c|c|c|c|c|}
\hline \multirow[t]{2}{*}{ Type } & \multicolumn{4}{|c|}{ Recycled Coarse Aggregate (2) } & \multicolumn{2}{|c|}{ Recycled Fine Aggregate } \\
\hline & Type C1 & \multicolumn{2}{|c|}{ Type C2 } & Type C3 & Type F1 & Type F2 \\
\hline Absorption (\%) & 3 or less & 3 or less & 5 or less & 7 or less & 5 or less & 10 or less \\
\hline \multirow{2}{*}{$\begin{array}{l}\text { Sulfate } \\
\text { Soundness (\%) }\end{array}$} & \multirow[t]{2}{*}{12 or less } & 40 or less & 12 or less & \multirow[t]{2}{*}{-} & \multirow[t]{2}{*}{10 or less } & \multirow[t]{2}{*}{ - } \\
\hline & & 40 & $(1)$ & & & \\
\hline
\end{tabular}

Notes:

(1) Where freezing and thawing resistance is not required;

(2) Grading and content of injurious impurities are also stipulated. 
Table 2: Types of Recycled Aggregate Concrete and Suggested Uses in Civil and Building Works [11]

\begin{tabular}{|c|c|c|c|c|}
\hline \multicolumn{5}{|c|}{ Civil Works Applications } \\
\hline Type & Coarse Aggregate & Fine Aggregate & $\begin{array}{l}\text { Suggested Design } \\
\text { Strength (MPa) }\end{array}$ & $\begin{array}{l}\text { Suggested Use of Recycled } \\
\text { Aggregate Concrete }\end{array}$ \\
\hline $\mathrm{CI}$ & $\begin{array}{l}\text { Recycled Coarse } \\
\text { Aggregate Type } \\
\text { C1 }\end{array}$ & $\begin{array}{l}\text { Normal Fine } \\
\text { Aggregate }\end{array}$ & 18 to 24 & $\begin{array}{l}\text { Reinforced or plain concrete; lower } \\
\text { structure of bridges, tunnel lining, } \\
\text { retaining walls, etc. }\end{array}$ \\
\hline CII & $\begin{array}{l}\text { Recycled Coarse } \\
\text { Aggregate Type } \\
\text { C2 }\end{array}$ & $\begin{array}{c}\text { Normal or } \\
\text { Recycled Fine } \\
\text { Aggregate Type } \\
\text { F1 }\end{array}$ & 16 to 18 & $\begin{array}{l}\text { Plain concrete; masonry units, bases } \\
\text { for road attachment, gutters, gravity } \\
\text { type retaining walls, etc. }\end{array}$ \\
\hline CIII & $\begin{array}{l}\text { Recycled Coarse } \\
\text { Aggregate Type } \\
\text { C3 }\end{array}$ & $\begin{array}{l}\text { Recycled Fine } \\
\text { Aggregate Type } \\
\text { F2 }\end{array}$ & Less than 16 & $\begin{array}{l}\text { Subslab concrete, back filling } \\
\text { concrete, leveling concrete, etc. }\end{array}$ \\
\hline \multicolumn{5}{|c|}{ Building Works Applications } \\
\hline $\mathrm{BI}$ & $\begin{array}{c}\text { Recycled Coarse } \\
\text { Aggregate Type } \\
\text { C1 }\end{array}$ & $\begin{array}{l}\text { Normal Fine } \\
\text { Aggregate }\end{array}$ & 18 or more & $\begin{array}{l}\text { Ordinary reinforced concrete } \\
\text { buildings }\end{array}$ \\
\hline BII & $\begin{array}{l}\text { Recycled Coarse } \\
\text { Aggregate Type } \\
\text { C2 }\end{array}$ & $\begin{array}{l}\text { Normal Fine } \\
\text { Aggregate }\end{array}$ & 18 or more & $\begin{array}{l}\text { Concrete attached to ground; } \\
\text { foundation, cast-in-place concrete } \\
\text { piles, concrete slabs on steel decks, } \\
\text { etc. }\end{array}$ \\
\hline BIII & $\begin{array}{l}\text { Recycled Coarse } \\
\text { Aggregate Type } \\
\text { C2 }\end{array}$ & $\begin{array}{l}\text { Recycled Fine } \\
\text { Aggregate Type } \\
\text { F1 }\end{array}$ & 18 or more & $\begin{array}{l}\text { Foundation slabs, earthen floor } \\
\text { slabs, subslab concrete, back filling } \\
\text { concrete, leveling concrete, etc. }\end{array}$ \\
\hline BIV & $\begin{array}{c}\text { Recycled Coarse } \\
\text { Aggregate Type } \\
\text { C3 }\end{array}$ & $\begin{array}{l}\text { Recycled Fine } \\
\text { Aggregate Type } \\
\text { F2 }\end{array}$ & 18 or more & $\begin{array}{l}\text { Subslab concrete, back filling } \\
\text { concrete, leveling concrete, etc. }\end{array}$ \\
\hline
\end{tabular}


Table 3: Potential Areas of Application of Recycled Materials [33]

\begin{tabular}{|c|c|c|}
\hline Recycled Material & Use & Areas of Application \\
\hline \multirow{7}{*}{ Crushed Concrete } & \multirow[t]{10}{*}{ As Aggregate } & Concrete Roads and Aprons \\
\hline & & Drainage Work \\
\hline & & Shallow Storage Tanks \\
\hline & & Pipes and Culverts \\
\hline & & Sewage / Water Treatment Plants \\
\hline & & $\begin{array}{lll}\begin{array}{l}\text { Permeable Backing } \\
\text { Retaining Structures }\end{array} & \text { to } & \text { Earth } \\
\end{array}$ \\
\hline & & $\begin{array}{l}\text { Bedding Materials to Reinforced } \\
\text { Concrete Structures }\end{array}$ \\
\hline \multirow[t]{3}{*}{ Crushed Concrete / Brick } & & Building Partition Walls \\
\hline & & Floors and Foundation \\
\hline & & Garbage / Refuse Disposal Plant \\
\hline Crushed Concrete & As Aggregate in New Asphalt & Base Course Materials in Pavement \\
\hline \multirow[t]{2}{*}{ Crushed Concrete / Brick } & \multirow[t]{2}{*}{ As Unbound Base Course } & Runways, Taxiway and Aprons \\
\hline & & Parking Lots and Other Yards \\
\hline $\begin{array}{l}\text { Crushed Concrete / Brick } \\
\text { or Recycled Aggregate } \\
(<4.75 \mathrm{~mm})\end{array}$ & As Fill Material & Cable Trenches \\
\hline
\end{tabular}


Table 4: Symbols Used for Representing Various Materials

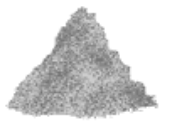

Fine Aggregate

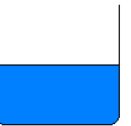

Half of the required Water

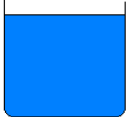

Water

Recycled Aggregate + Natural Coarse aggregate

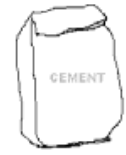

Cement
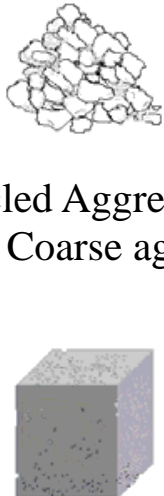

Concrete 
Table 5: Mix Proportions

\begin{tabular}{|c|c|}
\hline Ingredients of concrete & Mass (in kg) \\
\hline Ordinary Portland cement & 100 \\
\hline Fine aggregate & 180 \\
\hline 20mm coarse aggregate & 180 \\
\hline 10mm coarse aggregate & 90 \\
\hline
\end{tabular}


Table 6: Compressive Strengths and Percentages of Improvement in Different Proportions of

\section{RA Using NMA and TSMA}

\begin{tabular}{|c|c|c|c|c|c|c|c|c|c|c|c|c|c|}
\hline \multirow{2}{*}{\multicolumn{2}{|c|}{$\begin{array}{l}\text { Mixing } \\
\text { Methods }\end{array}$}} & \multicolumn{4}{|c|}{ Normal Mixing Approach (days) } & \multicolumn{4}{|c|}{$\begin{array}{l}\text { Two-Stage Mixing Approach } \\
\text { (days) }\end{array}$} & \multicolumn{4}{|c|}{ Improvement \% (days) } \\
\hline & & 7 & 14 & 28 & 56 & 7 & 14 & 28 & 56 & 7 & 14 & 28 & 56 \\
\hline \multirow{6}{*}{$\begin{array}{c}\text { Compressive } \\
\text { Strength } \\
(\mathrm{MPa})\end{array}$} & $0 \%$ & 43.87 & 53.01 & 55.72 & 67.60 & 45.0 & 54.0 & 56.0 & 68.0 & $2.59 \%$ & $1.86 \%$ & $0.51 \%$ & $0.59 \%$ \\
\hline & $10 \%$ & 50.29 & 54.53 & 58.98 & 74.60 & 54.0 & 61.4 & 64.5 & 79.2 & $7.41 \%$ & $12.62 \%$ & $9.41 \%$ & $6.18 \%$ \\
\hline & $15 \%$ & 45.14 & 51.72 & 56.26 & 70.19 & 49.6 & 55.7 & 61.3 & 72.4 & $9.83 \%$ & $7.67 \%$ & $8.88 \%$ & $3.15 \%$ \\
\hline & $20 \%$ & 42.21 & 51.92 & 53.68 & 68.84 & 45.1 & 56.6 & 65.1 & 72.0 & $6.96 \%$ & $9.02 \%$ & $21.19 \%$ & $4.64 \%$ \\
\hline & $25 \%$ & 51.09 & 52.62 & 52.31 & 67.23 & 53.0 & 57.1 & 63.1 & 77.7 & $3.82 \%$ & $8.44 \%$ & $20.64 \%$ & $15.61 \%$ \\
\hline & $30 \%$ & 45.49 & 54.58 & 58.07 & 72.78 & 54.8 & 60.6 & 66.2 & 77.5 & $20.46 \%$ & $11.05 \%$ & $13.94 \%$ & $6.44 \%$ \\
\hline
\end{tabular}




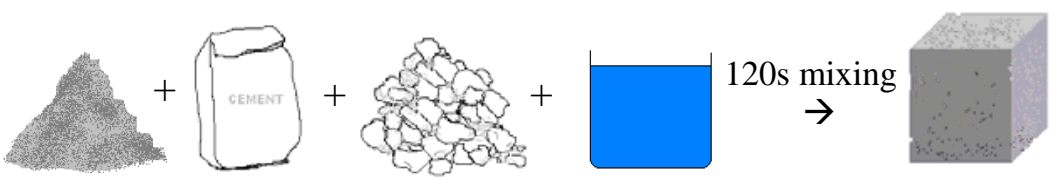

(i) NMA

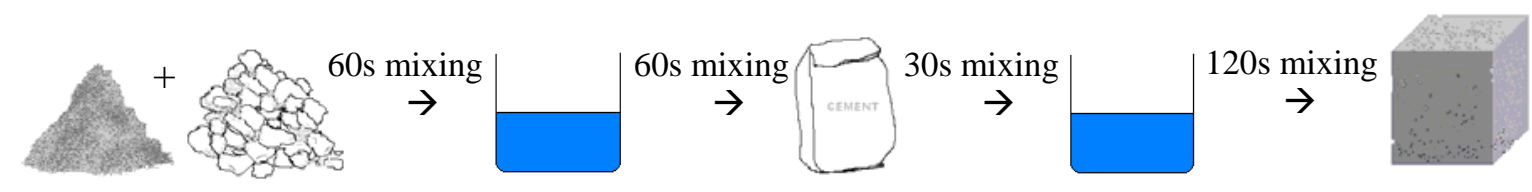

(ii) TSMA

Figure 1: Mixing Procedures of the (i) Normal Mixing Approach and

(ii) Two-Stage Mixing Approach 


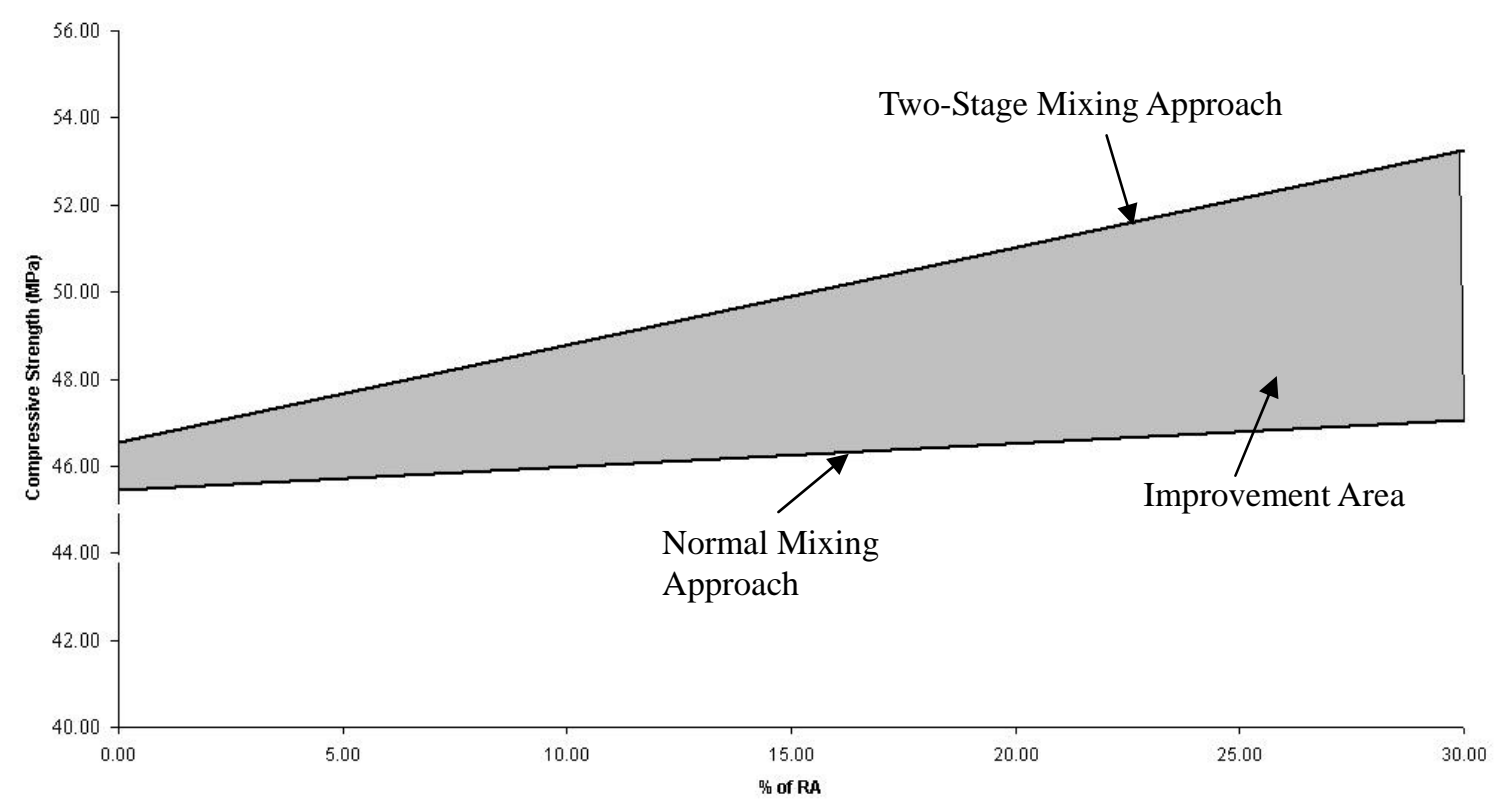

Figure 2: 7-day Compressive Strengths Using Normal Mixing Approach and Two-Stage Mixing Approach 


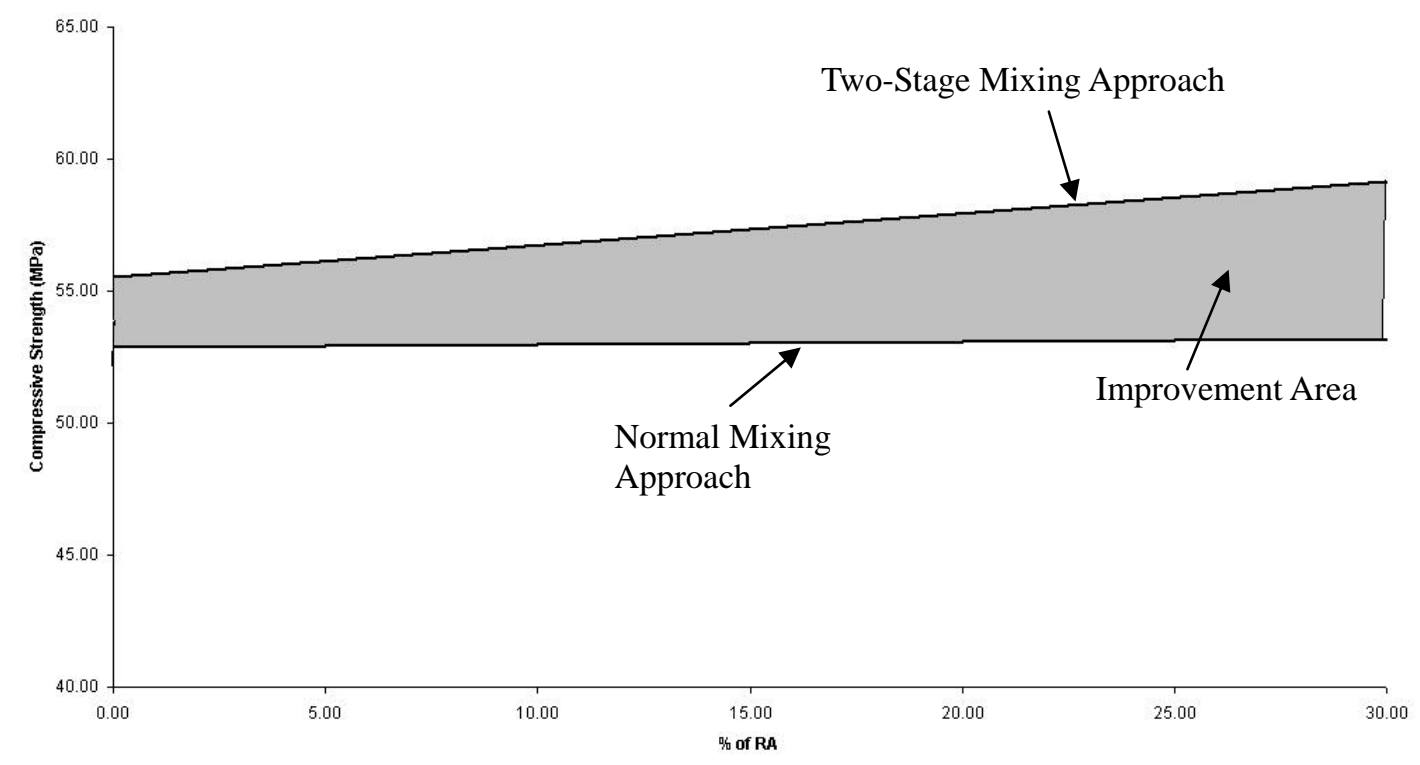

Figure 3: 14-day Compressive Strengths Using Normal Mixing Approach and Two-Stage Mixing Approach 


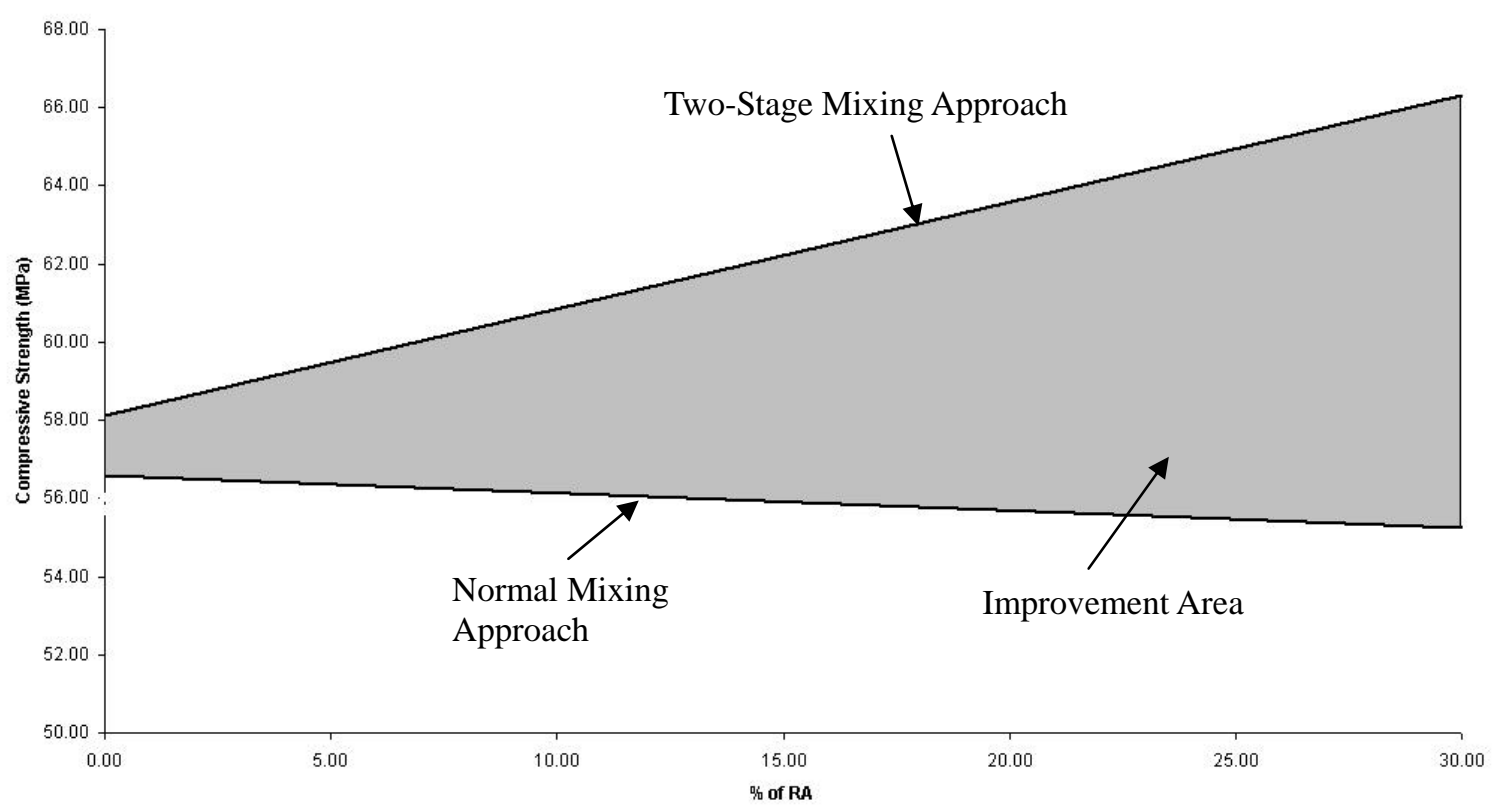

Figure 4: 28-day Compressive Strengths Using Normal Mixing Approach and Two-Stage Mixing Approach 


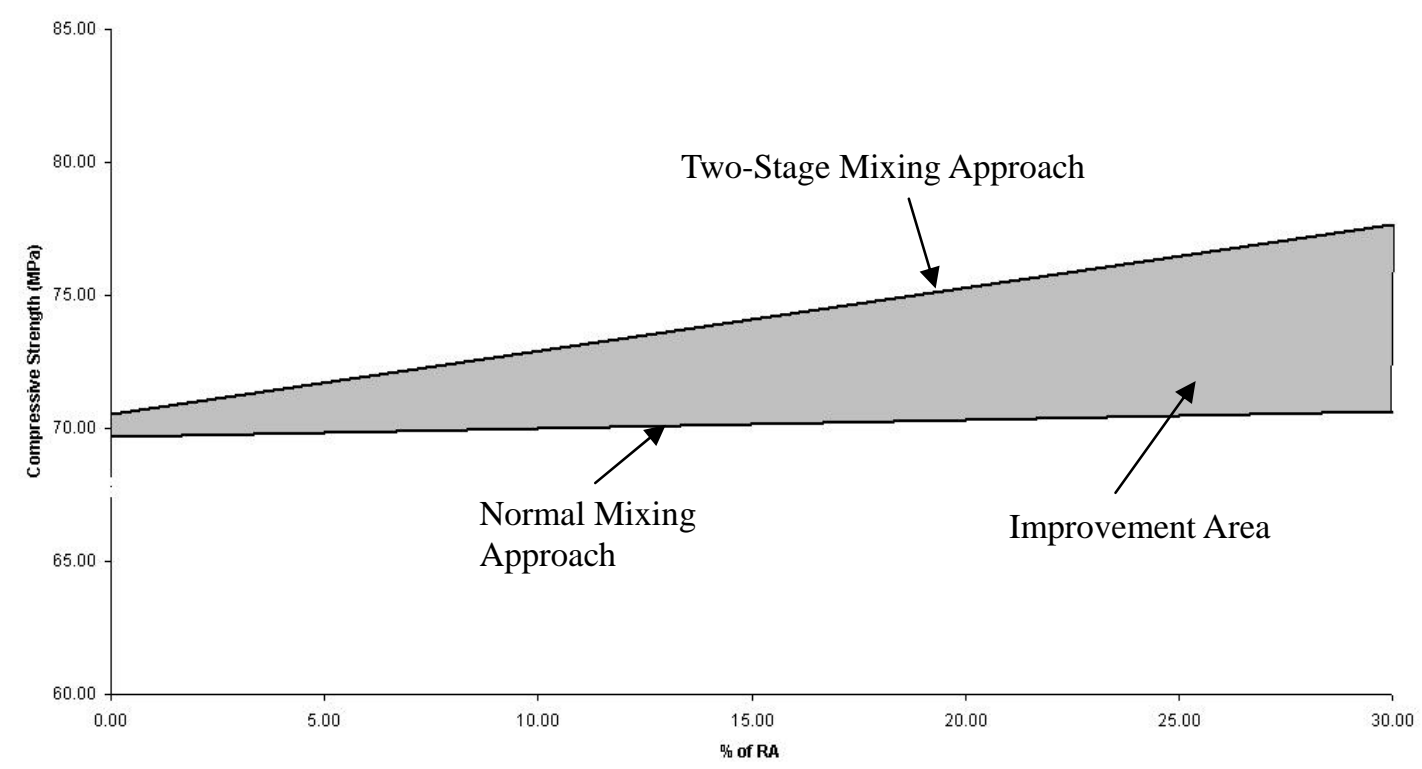

Figure 5: 56-day Compressive Strengths Using Normal Mixing Approach and Two-Stage Mixing Approach 


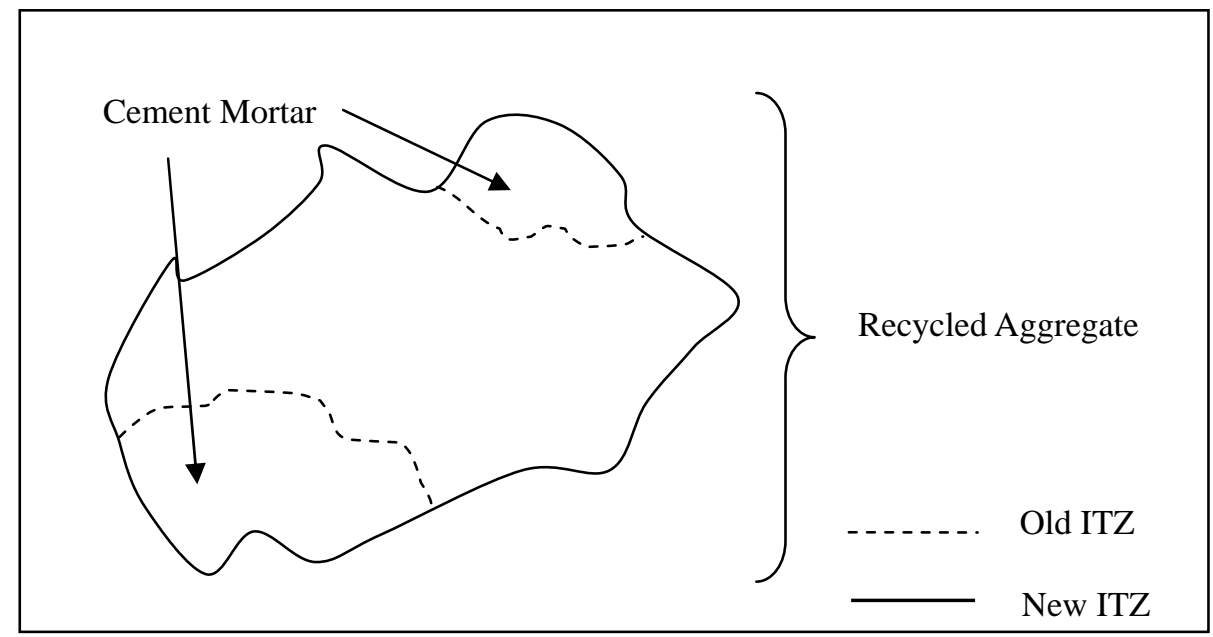

Figure 6: Interfaces of Recycled Aggregate 


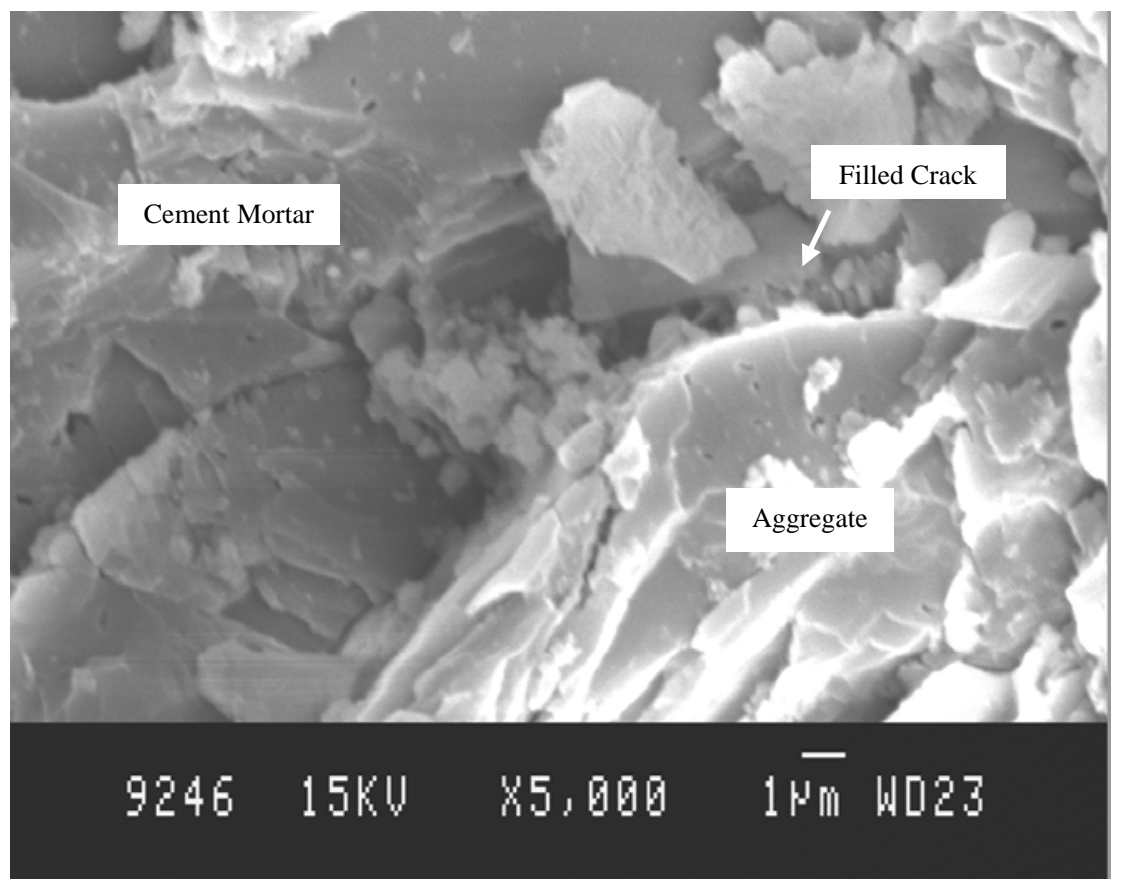

Figure 7: Filled Crack in RA using TSMA 


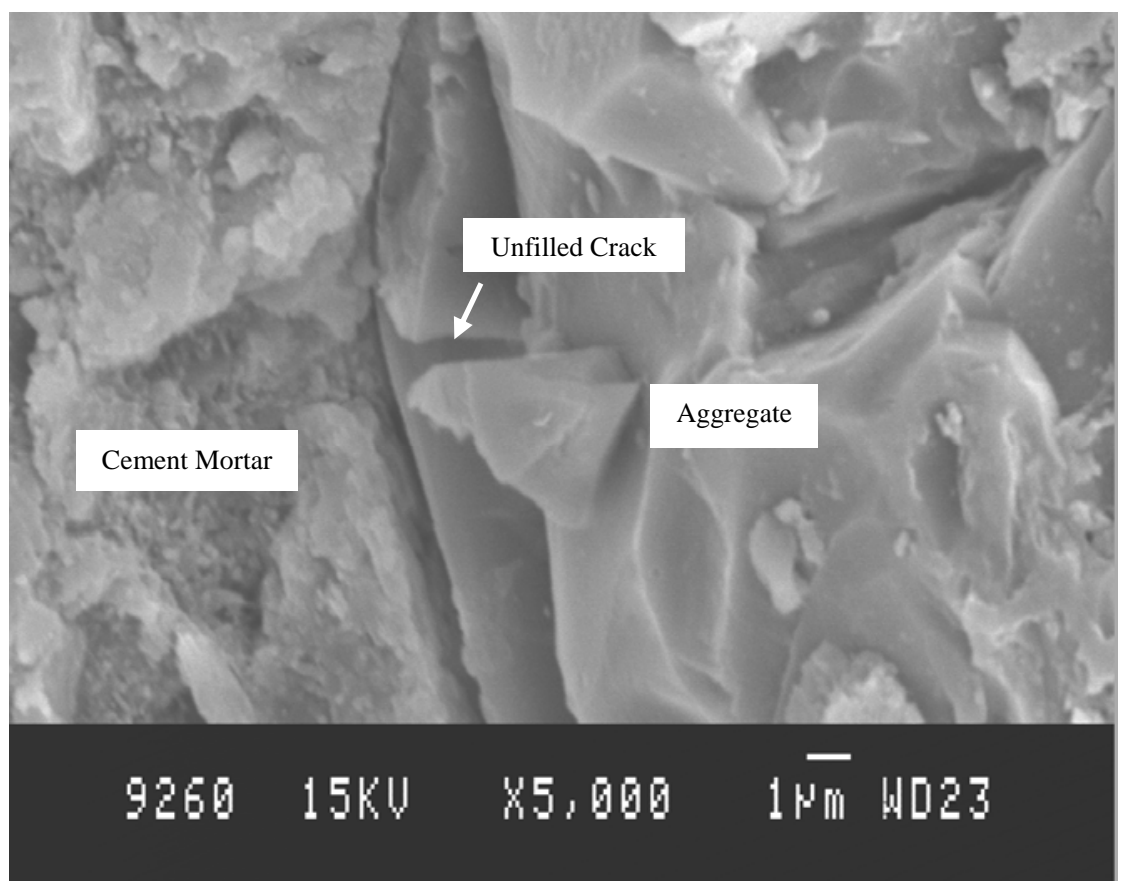

Figure 8: Unfilled Crack in RA using NMA 


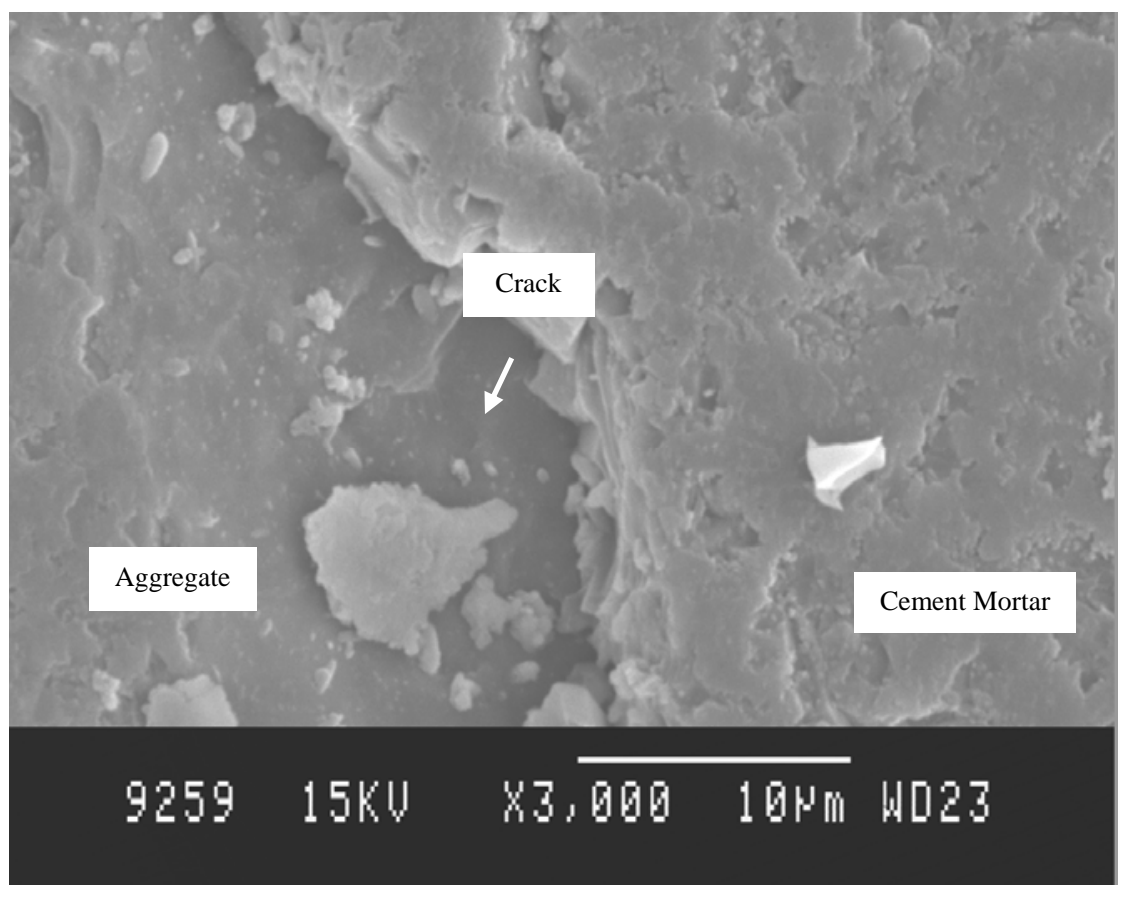

Figure 9: Crack in RA using NMA 


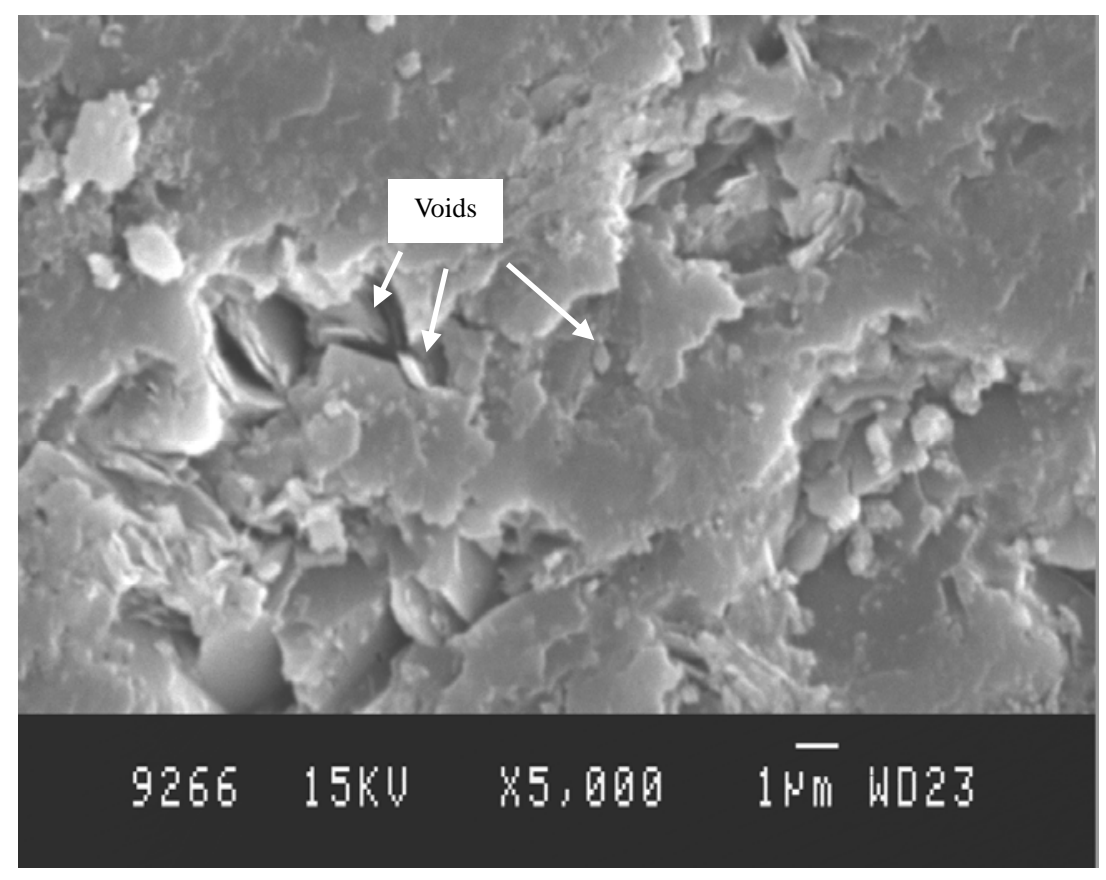

Figure 10: Voids in RA using NMA 


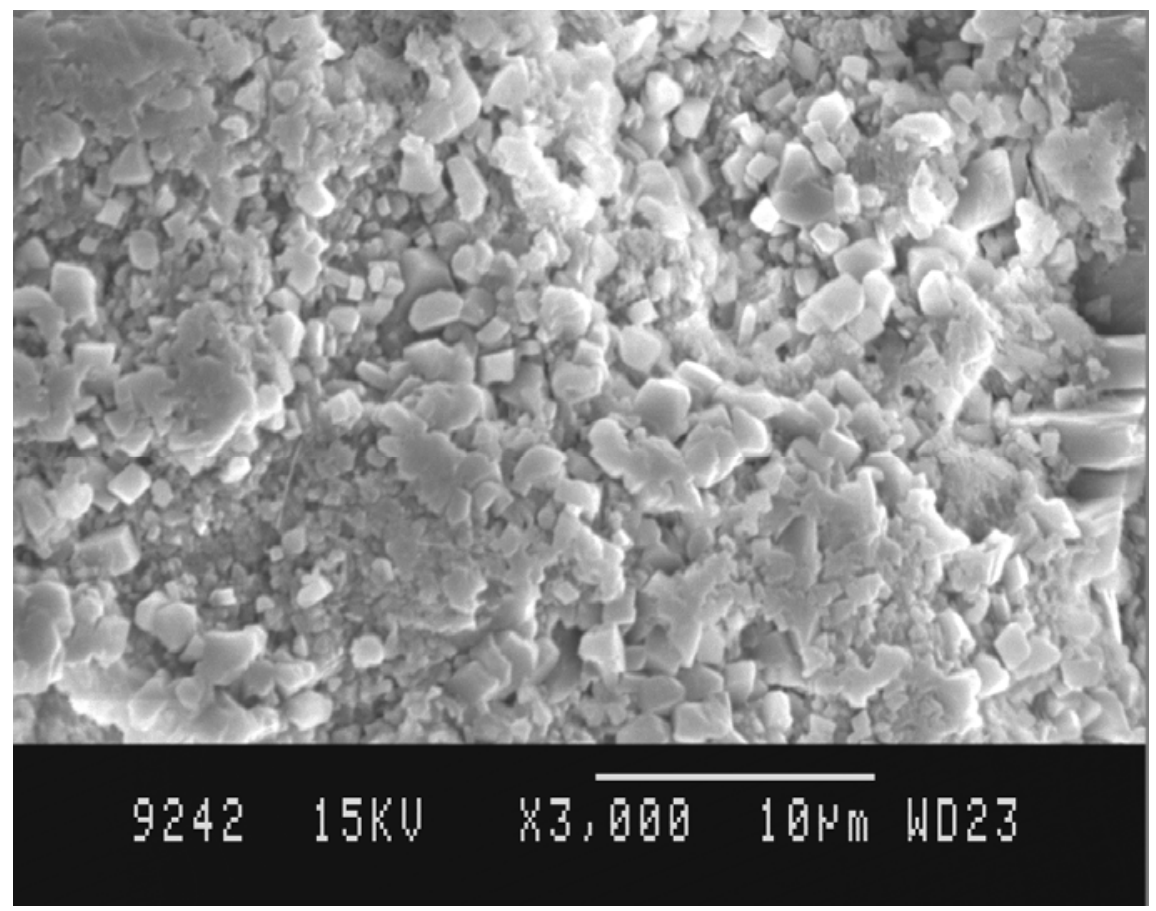

Figure 11: Dense Cement Paste for TSMA 


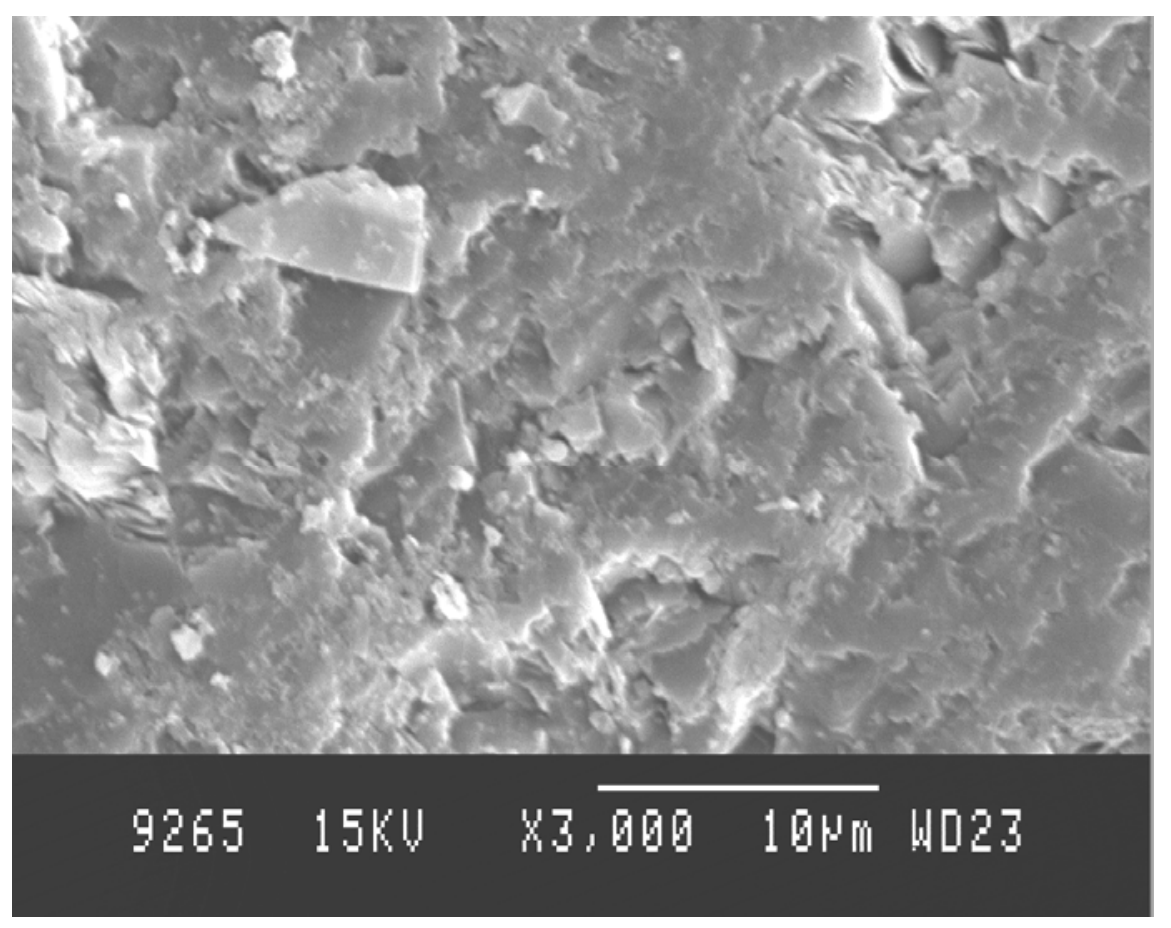

Figure 12: Loose Cement Paste for NMA 


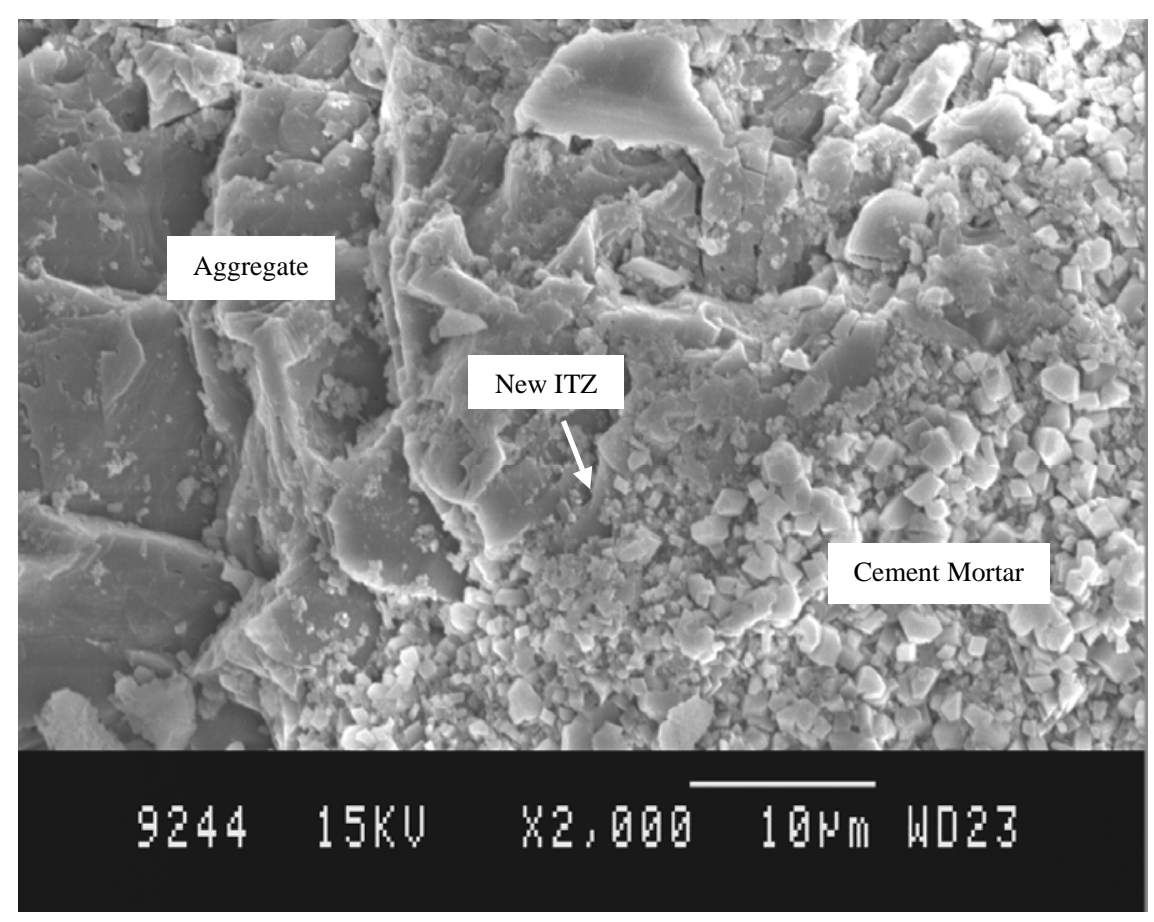

Figure 13: New Interfacial Zone for TSMA 


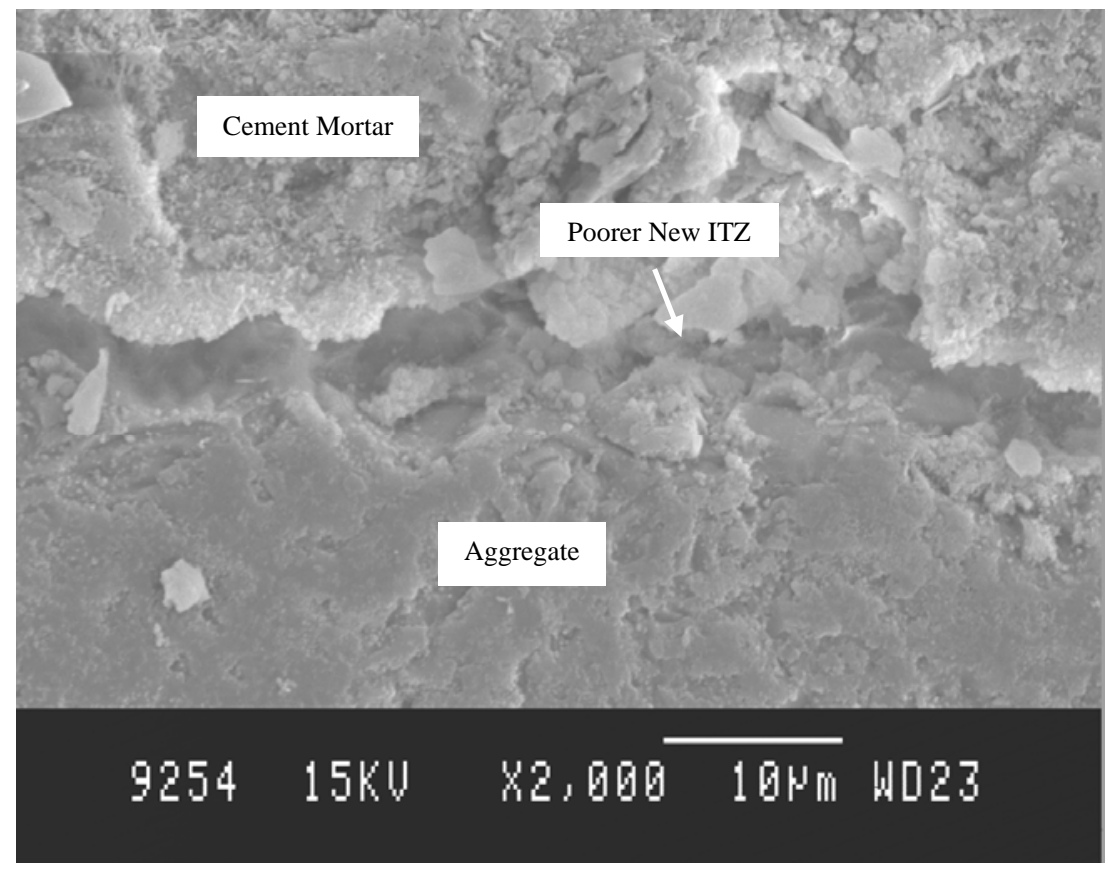

Figure 14: Poorer New Interfacial Zone for NMA 


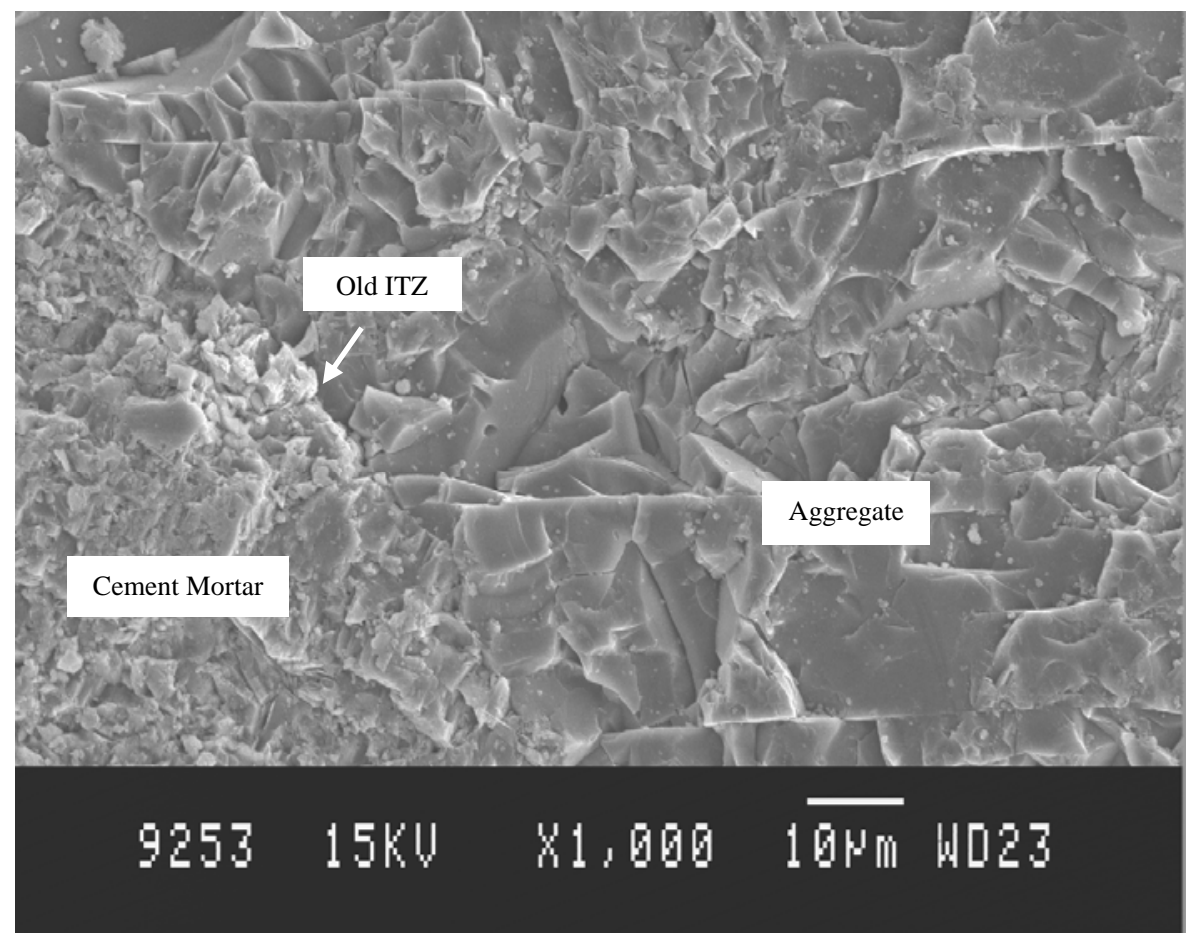

Figure 15: Old Interfacial Zone for TSMA 


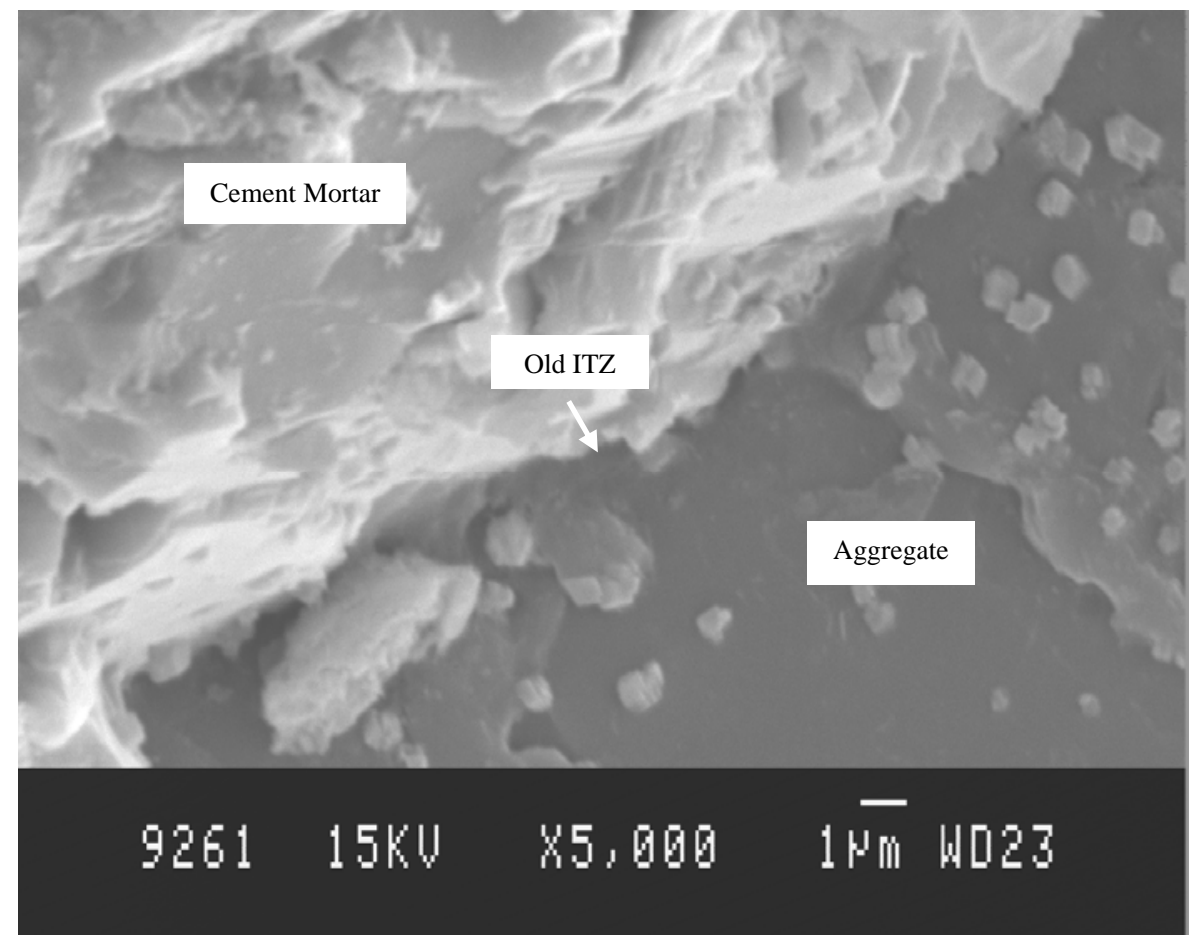

Figure 16: Old Interfacial Zone for NMA 


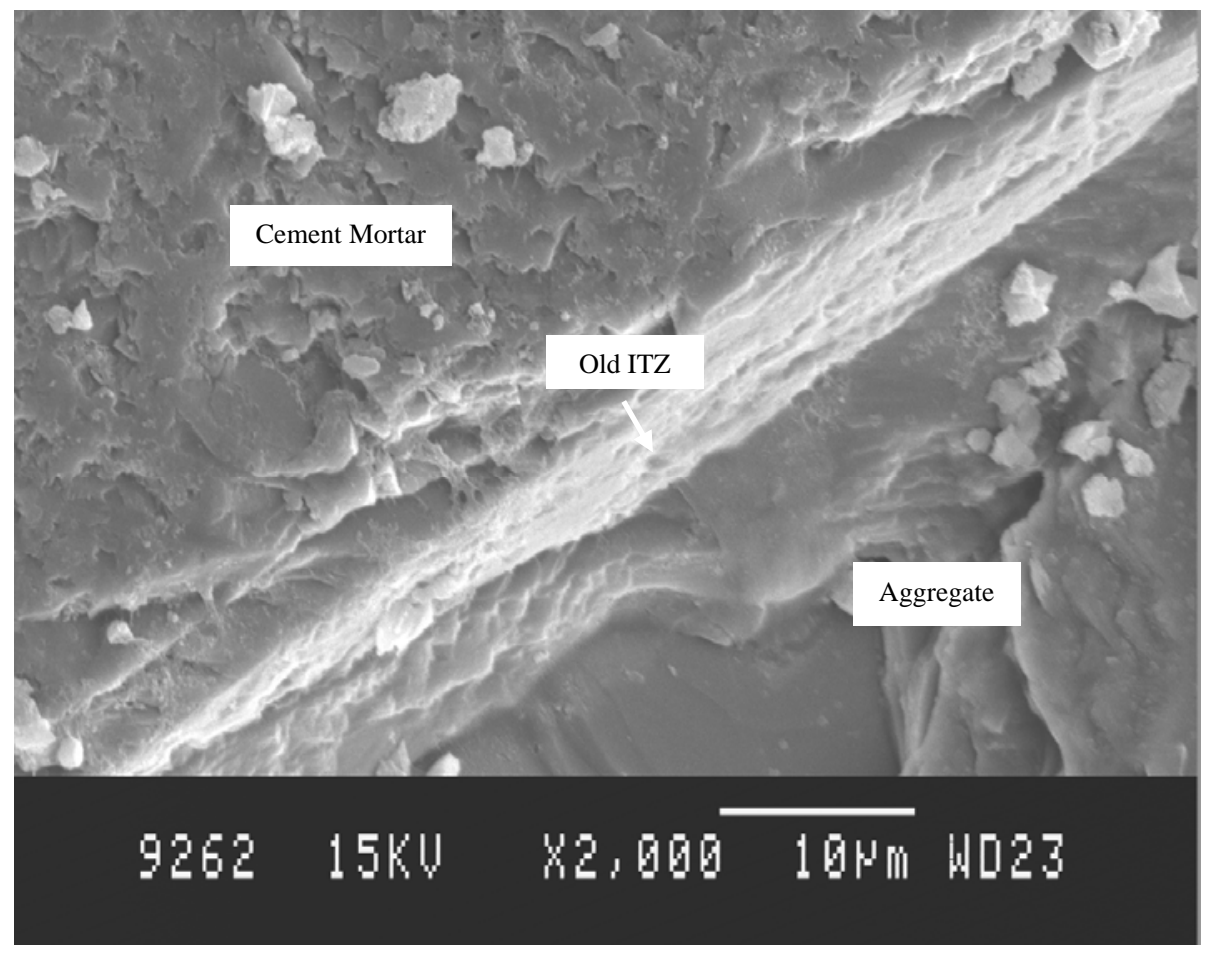

Figure 17: Old Interfacial Zone for NMA 


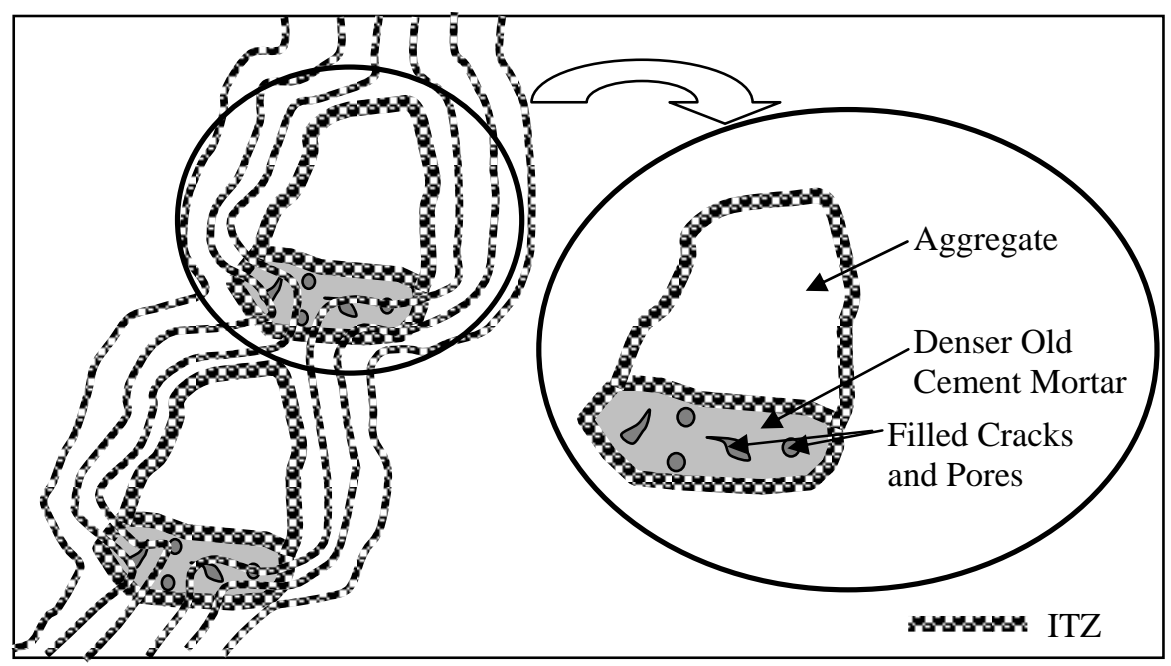

Figure 18: RA Structure after Adopting TSMA 